\title{
Not only the butterflies: managing ants on road verges to benefit Phengaris (Maculinea) butterflies
}

\author{
Irma Wynhoff · René van Gestel · Chris van Swaay • \\ Frank van Langevelde
}

Received: 12 April 2010/Accepted: 19 August 2010/Published online: 19 September 2010

(C) The Author(s) 2010. This article is published with open access at Springerlink.com

\begin{abstract}
Obligate myrmecophilic butterfly species, such as Phengaris (Maculinea) teleius and P. nausithous, have narrow habitat requirements. Living as a caterpillar in the nests of the ant species Myrmica scabrinodis and M. rubra, respectively, they can only survive on sites with both host ants and the host plant Great Burnet Sanguisorba officinalis. After having been reintroduced into a nature reserve in the Netherlands in 1990, both butterfly species expanded their distribution to linear landscape elements such as road verges and ditch edges outside this reserve. As additional habitat of both butterfly species, vegetation management of these landscape elements became important. Our results show that a management beneficial for Phengaris butterflies should aim to increase the nest density of Myrmica species, at the same time reducing the density of nests of the competitor Lasius niger or at least keeping them at a low density. Unfavourable grassland management under which L. niger thrives, includes not mowing or flail-cutting the grass, or depositing dredgings along the side of the ditch. Management favourable for the two Myrmica species differs, demanding some flexibility if both species are to benefit. M. scabrinodis is best supported with early mowing of the road verge vegetation or late mowing in the
\end{abstract}

I. Wynhoff $(\bowtie) \cdot$ R. van Gestel · C. van Swaay

Dutch Butterfly Conservation, P.O. Box 506, 6700 AM

Wageningen, The Netherlands

e-mail: Irma.Wynhoff@vlinderstichting.nl

I. Wynhoff · C. van Swaay

Butterfly Conservation Europe, P.O. Box 506, 6700 AM

Wageningen, The Netherlands

R. van Gestel · F. van Langevelde

Resource Ecology Group, Wageningen University,

Droevendaalsesteeg 3a, 6708 PB Wageningen, The Netherlands nature reserve, both of which result in an open vegetation and warm microclimate. In contrast, the nest sites of M. rubra should be left undisturbed during the summer, and mown in late autumn. Mowing of butterfly habitat should be avoided between mid-June and mid-September as this would remove the flowerheads of the Sanguisorba plants, on which the butterflies lay their eggs.

Keywords Myrmica · Ant community - Conservation management $\cdot$ Road verge management $\cdot$ Reintroduction

\section{Introduction}

Sometimes actions in nature conservation have surprising results. The reintroduction of two Large Blue butterfly species, Phengaris (Maculinea) teleius and P. nausithous, into the Netherlands is a case in point. Released in 1990 into the nature reserve Moerputten in the southern province Noord-Brabant (Wynhoff 1998), they expanded their distribution outside the protection of this reserve, occupying the verges of roads running between agricultural fields. Until the 1970s, both species had occurred on meadows and pastures in stream valleys in the middle and south of the Netherlands; the last populations were eradicated by agricultural intensification. Since both species have an obligate relationship with Myrmica ants (Thomas and Settele 2004), the success of the reintroduction depended not only on the host plant Sanguisorba officinalis being abundant, but also large numbers of the host ant species were needed to provide suitable habitat. The new populations developed well and showed a considerable increase in numbers (Van Langevelde and Wynhoff 2009). P. teleius only colonized the meadow where it was released and hardly dispersed to other locations. Recently, however, 
various subpopulations developed outside Moerputten at distances ranging from 1.5 to 5 kilometres, mostly on road verges and in another nearby nature reserve. The Dusky Large Blue, $P$. nausithous also settled first in Moerputten nature reserve, establishing a subpopulation on road verges south of the reserve after only 3 years. Later, two new subpopulations of $P$. nausithous were found at distances of 2 and 5 kilometres from the reintroduction site, one on a road verge. It became obvious that the habitat quality of the road verges, ditch edges and embankments was very important for the long-term persistence of both species (Van Langevelde and Wynhoff 2009). The road verges could fulfil a role not only as a dispersal corridor but also as temporary or permanent habitat (Haddad 2000). The question was how should such linear landscape elements as road verges be managed to facilitate the spread of these two butterfly species?

The caterpillars of $P$. teleius and $P$. nausithous spend about 10 months in the nests of Myrmica scabrinodis and M. rubra respectively feeding on ant larvae. The eggs of both butterfly species are deposited on the only host plant Sanguisorba officinalis (Thomas 1984). Hence, the suitability of a certain habitat patch is determined by the abundance of both the host plant and the specific host ants (Van Dyck et al. 2000 (for P. alcon); Wynhoff et al. 2008; Anton et al. 2008; Dierks and Fischer 2009; Batáry et al. 2009). In and around the nature reserve Moerputten, the density of ant nests is much lower than that of the host plants (Wynhoff et al. 2008; Van Langevelde and Wynhoff 2009). On road verges, too, and in some other nature reserves, the host plant density is also high, whereas it is missing in the pastures and fields under agricultural use. As both these plants and the ants are sensitive to management (Dahms et al. 2005; Grill et al. 2008), the province of Noord-Brabant designated the "Maculinea Action Plan Area" to stimulate an increase in the density of Myrmica ant nests and further dispersal of the Phengaris populations (Provincie Noord-Brabant 1997).

Within Europe, ants of the genus Myrmica and the competitive species of the genus Lasius are common and widespread (Seifert 1994, 1996; Van Loon and Mabelis 1996). Although each species occupies an ecologically distinct habitat, there is overlap in the distribution of species. On many sites, two or three Myrmica or Lasius species may occur in competition with each other (Elmes and Wardlaw 1982; Elmes et al. 1998). Myrmica rubra prefers warm and moist habitats consisting of rough grassy vegetation along edges of bogs, rivers and woods. Myrmica scabrinodis occurs on the short and open vegetation of slightly more thermophilous grasslands and on bogs and moors. The workers of Lasius flavus build very large nest mounds and are, like Myrmica species, sensitive to disturbance. Lasius niger is a rapid colonizer of disturbed ground. Able to stand high levels of disturbance, it is a serious competitor of Myrmica ants (Peeters et al. 2004).

Besides geographical differences, ant communities are structured by vegetation characteristics in relation to prey abundance and intraspecific and interspecific competition (Dauber and Wolters 2000). The vegetation may be changed by various factors such as disturbances or management, leading to direct and indirect effects on the ant communities. Direct effects include destruction of nests and reduction of ant biomass (Heller and Rohe 2000). However, the indirect effects are considered to be much more important (Elmes and Wardlaw 1982; Curry 1994; Elmes et al. 1998; Kruess and Tscharntke 2002; Armbrecht et al. 2004). The changes in vegetation structure (height and density of plants, plant species richness) and soil conditions brought about by disturbance, leads to changes in microclimate, food supply and habitat structure. The indirect effects of various types of management on ant communities have been studied on the scale of agricultural fields under various types of agricultural use (Dahms et al. 2005; Dauber et al. 2006) and in an experiment on meadows (Grill et al. 2008). But we know very little about the effect of various types of management on the presence and abundance of Myrmica ants on road verges and stream borders, where the vegetation is similar to that in hay meadows and extensively grazed pastures, and which is subject to frequent management.

In the years after reintroducing the butterflies, we monitored the distribution of the adults intensively in order to study factors influencing the selection of oviposition sites (Wynhoff et al. 2008) and the limitations for their spread (Van Langevelde and Wynhoff 2009). We also monitored the presence and abundance of ant nests in and around the nature reserve Moerputten over several years. In this paper, we seek to explain what determines the presence and abundance of Myrmica ants over time by testing various factors. We study whether there are management measures that can be taken to influence the presence and abundance of ants positively. Our results will help government and NGOs to design refined management strategies to promote the highly specialized Phengaris butterflies.

\section{Materials and methods}

Our study area covers the nature reserve Moerputten in the Dutch province of Noord-Brabant $\left(51^{\circ} 41^{\prime} \mathrm{N}, 5^{\circ} 15^{\prime} \mathrm{E}\right.$, altitude $2 \mathrm{~m}$ above sea level, for further description see Wynhoff 1998) and surroundings, extending to the river Maas in the north to the Drongelens Kanaal in the south (Fig. 1a). In the Action Plan Area (Fig. 1b), we randomly chose 179 plots with host plants to monitor the ant 

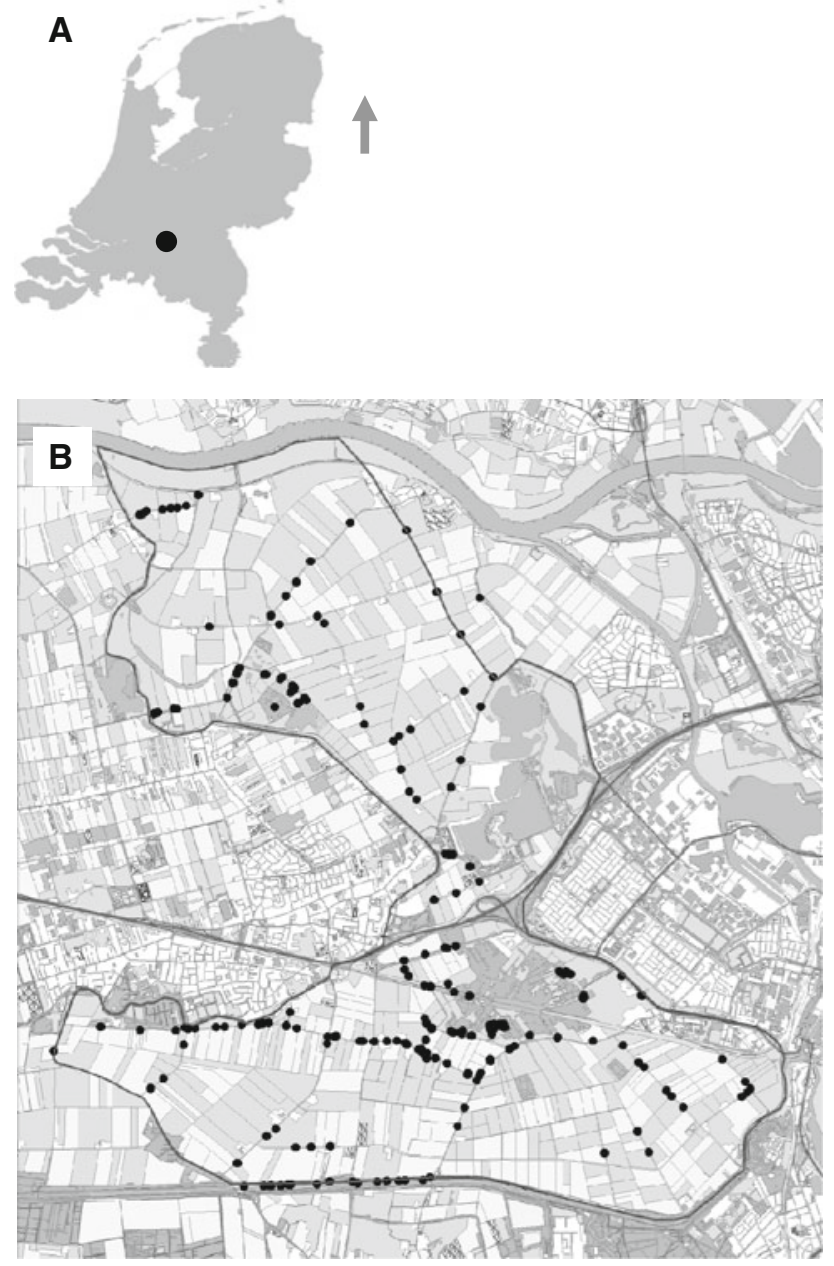

Fig. 1 a Location of the study area, Moerputten nature reserve and surroundings in the Netherlands, and $\mathbf{b}$ the distribution of ant plots in the study area, i.e. in the nature reserves, on the road verges, on the railway embankment and along streams

Table 1 Overview of results of ant monitoring in the nature reserve Moerputten and surrounding road verges, ditch sides and other nature reserves per year of investigation

\begin{tabular}{lrrrrr}
\hline & 1996 & 2000 & 2003 & 2006 & 2009 \\
\hline Number of plots & 179 & 179 & 193 & 193 & 208 \\
Number of plots with ants & 139 & 112 & 85 & 117 & 157 \\
\% Occupied with ants & 77 & 63 & 44 & 61 & 75 \\
Number of plots with Myrmica & 65 & 67 & 40 & 68 & 85 \\
\% Occupied with Myrmica & 36 & 37 & 21 & 35 & 41 \\
Nr. of species found & 10 & 9 & 10 & 9 & 9 \\
Mean nr of species per plot & 2,32 & 1,90 & 1,28 & 1,79 & 2,39 \\
\pm SE & 1,54 & 1,63 & 1,55 & 1,61 & 1,69 \\
Max. nr of species per plot & 6 & 5 & 6 & 6 & 7 \\
\hline
\end{tabular}

community (up to 208 plots in 2009; Table 1). Using GPS, we recorded the coordinates of each plot, in addition to field maps and site descriptions.
Ant monitoring was carried out in June, July or August in the years 1996, 2000, 2003, 2006, and 2009 on dry days warmer than $17^{\circ} \mathrm{C}$. Each plot was searched during exactly 15 min for ants in an area of about ten square metres around one or more Sanguisorba plants. Since it is impossible to determine the exact density of ant nests on plots of equal size and achieve high sample sizes at the same time, we chose to keep the search effort of 15 min equal to be able to compare the results. All plots in nature reserves were distinguished from the road verge plots. On plots along road sides we searched the whole gradient from dry strips close to the asphalt to the humid bottom of the road side ditches. Worker ants appear from their nest in the soil by disturbing the soil with a knife and by plucking at vegetation. We recorded both the presence of an ant species as well as the (relative) density of their nests (here called abundance). Some of the worker ants were collected for later identification in the lab, using keys of Van Boven and Mabelis (1986) and Seifert (1994, 1996). By actively searching for ants, the results are independent from the behaviour of the worker ants and largely independent from weather conditions.

Apart from the ant community, we also recorded the direction of the slope of the plot and its distance to the nearest tree or shrub as proxy of microclimatic conditions possibly affecting the ant community (Armbrecht et al. 2004). Furthermore, during 2006 and 2009 we consistently assessed the management by the responsible municipality. Since during the flight period from the end of July to mid-August, host plants with buds must be available for oviposition, the time of mowing is an important aspect of management. It means that cutting must not happen later than early June, to avoid that regrowth would be too young to produce new flowers. Furthermore, the host plants should not be cut before midSeptember after the caterpillars have left the flowerheads and stay safe in the ant nests. We distinguished seven management types: (1) early mowing before mid-June, (2) late mowing after mid-September, (3) partly mown, (4) mown and removed between mid-June and mid-September, (5) not mown, (6) flail cutting, and (7) covered with dredged ditch sediment. Usually, grass is cut and the hay is removed immediately or within a week except for flail cutting, which tears the grass into pieces and leaves it behind on the spot. Since 1997, management was done according to the Maculinea Action Plan which implies that mowing is avoided between mid-June and mid-September in order to increase the amount of habitat of the butterflies. Also, flail cutting should be avoided.

Statistical analysis

We tested the influence of the variables mentioned above on the presence-absence and the abundance of all ant species combined, all Myrmica species together, and the four main 
ant species separately (Myrmica rubra, M. scabrinodis, Lasius flavus and L. niger). Because the mobility of ant colonies is limited, it is likely that an ant species is still present during the next three or 4 years after it has been found during a certain year. To correct for this dependence between years, we used Generalized Estimation Equations (GEEs, Zeger et al. 1988). When running tests on presence-absence patterns, we used the binomial distribution with the logit-link function. The abundances were studied assuming a normal distribution using the identity-link function. We used the categorical variables year, municipality, slope direction and distance to trees (because we approximated this distance, we used distance classes) as predictor variables. We distinguished several expositions of the slope: north, northeast, east, southeast, south \& southwest (added together), west, northwest and flat. As the ubiquitous ant species L. niger can be an important competitor of Myrmica ants that can easily colonize disturbed sites, we used its abundance as an additional covariate when working on the presence-absence and abundance of all Myrmica or Lasius species together or separately (M. rubra, M. scabrinodis and L. flavus). For the significant categorical variables, we tested the pairwise comparisons using the Least Significant Differences adjustment (LSD) to find significant differences between the groups. By adding and removing predictor variables, we selected the best model using the Corrected Quasi Likelihood under Independence Model Criterion (QICC) that combines the highest number of factors and covariates explaining the variation in the tested dependent variable (low QICC values indicate more parsimonious models).

To test the effect of the various types of road verge management on the presence-absence and abundance of all ant species combined, all Myrmica ants, and the four main ant species (M. rubra, M. scabrinodis, L. flavus and L. niger) for the years 2006 and 2009 together, we used Generalized Linear Models (GLM). For presence-absence, we again used the binomial distribution with the logit-link function, and we applied a normal distribution with identity-link function for the abundances. We used the categorical variable management type as a predictor variable. We applied LSD pairwise comparisons to find significant differences between the given types of management. Plots in nature reserves were excluded from the analysis of management effects because the ant community was found to be too deviating from the communities on the road verges. We could not prove that this was independent from factors other than management.

\section{Results}

We found that most of the plots were occupied with ants in 1996 and 2009, with the lowest level of occupation in 2003
(Table 1). The percentage of plots with Myrmica ants was also lowest in 2003, while in the other years occupation was similar. The number of ant species found per year was remarkably stable: 9 or 10 ant species per year, with maximally 5 to 7 species in one plot on 1 day. Mean ant species richness between 1.3 and 2.4 seems to be low, but one has to consider the small plot size, when comparing the data with that in the literature. The most widespread and abundant ant species in all years were M. scabrinodis, M. rubra, L. flavus and L. niger. Their changes in occupation are given in Fig. 2. Furthermore, in all years, we also found M. ruginodis, M. sabuleti, M. rugulosa, Formica fusca and $F$. rufibarbis, but only on a small number of plots with a few colonies. The rare $M$. rugulosa is the only ant species that is found in the study area only in the nature reserves. Some species, namely Lasius umbratus, Tetramorium caespitum, Leptothorax acervorum, Leptothorax nylanderi and Ponera coarctata were even rarer, being found in only one or two of the years we monitored.

Striking differences appeared, when comparing the percentage of occupied plots of the four most common species between the municipalities and the nature reserves (Fig. 3). L. flavus is the only ant species found in almost equal percentages in all three municipalities and in the nature reserves. $M$. scabrinodis occurs much more in nature reserves than on road verges and ditch edges, whereas L. niger reaches its highest occupation outside nature reserves. $M$. rubra was not encountered in the municipality of Den Bosch, but only in those of Heusden and Vught, as well as the nature reserves, with the highest percentage of occupation in Vught.

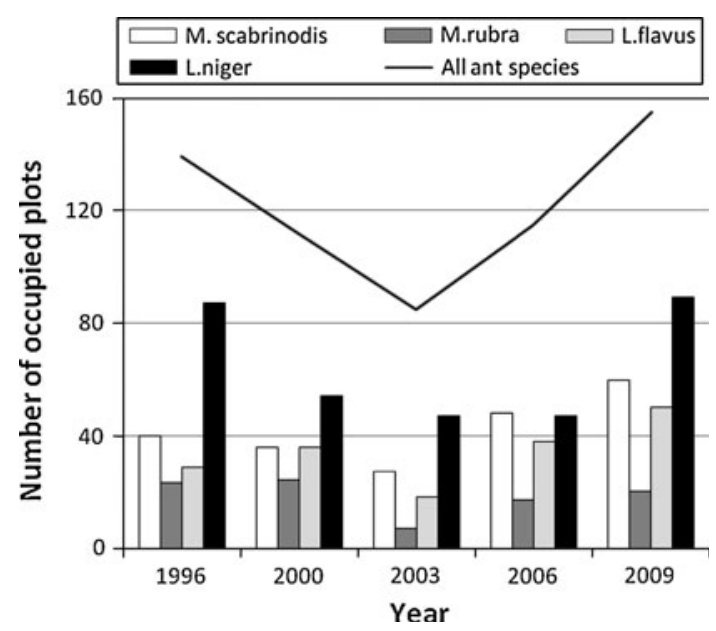

Fig. 2 Number of occupied monitoring plots in each of the 5 years investigated for the four main ant species and the number of all plots occupied by any ant species. The data were collected on 179 plots in Moerputten nature reserve and its surroundings in the Netherlands 


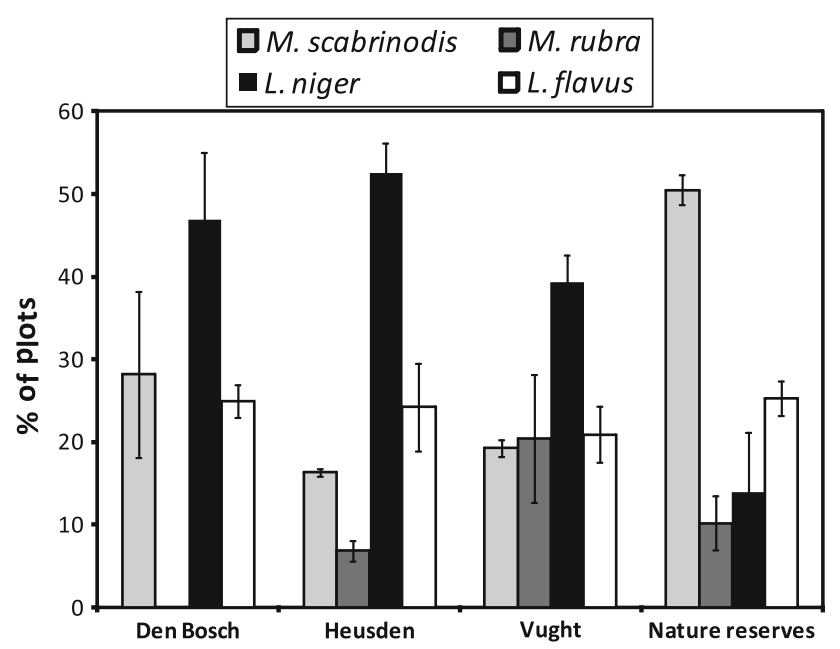

Fig. 3 Comparison of the percentage (and standard deviation) of monitoring plots occupied by Myrmica scabrinodis, M. rubra, Lasius niger or L. flavus between the municipalities and the nature reserves in the study area Moerputten and its surroundings in the Netherlands

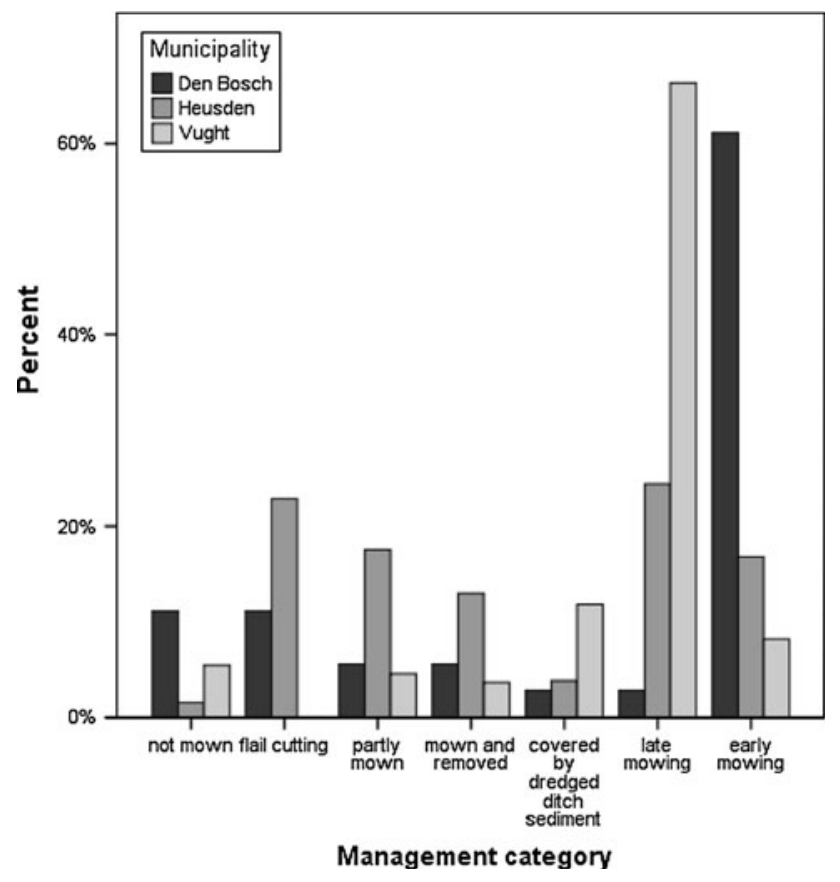

Fig. 4 Percentage of management category on road verge plots in the municipalities Den Bosch, Heusden and Vught (Province of NoordBrabant, The Netherlands)

Management practices of the municipalities

Management of the road verges differed between the various municipalities (Fig. 4). Within the borders of Den Bosch, most plots were mown before mid-June. A number of plots were not mown or were subject to flail cutting. In contrast, the municipality of Vught has most plots mown late in the year after mid-September. Here, on the one hand, flail cutting is not used within the borders of the Maculinea Action Plan Area, but on the other hand, the percentage of plots covered with dredged ditch material is highest. In the municipality of Heusden, the management techniques applied were most diverse, with no type being applied to more than $25 \%$ of the plots.

Changes in the ant community

The results of the GEE's are presented in Appendix A (presence-absence) and Appendix B (abundance). Mostly, predictors that are significant for the presence-absence patterns are also significant predictors of abundances, although in case of abundances, relationships are more pronounced. The presence-absence pattern of the whole ant community is explained by a combination of all variables investigated (Table 2, Appendix A1). In 2009 and 1996, the probability of finding an ant nest of any species on a plot was highest, followed by the years 2000 and 2006, whereas the probability was lowest in 2003. Nature reserves were more populated by ants than road verges and ditch edges, with the verges and ditch edges in the municipality of Vught having the lowest probability. Slopes with a southern or western exposition had a higher probability of being occupied than those with a northern one. Also, the distance to the nearest tree was of influence, although without showing a clear trend.

With the exception of the distance to the next tree, the abundance of ant species was explained by the same variables (Table 2, Appendix B1). Most colonies were found in nature reserves. The best year by far was 2009 and the highest density was found on slopes with a southern exposition. The management of the road verges also appeared to have an impact on the presence-absence pattern (GLM, Wald $\left.\chi^{2}=14.486, \mathrm{df}=6, P=0.025\right)$ and the abundance of the whole ant community (GLM, Wald $\left.\chi^{2}=424.341, \mathrm{df}=6, P<0.001\right)$. Most ant nests were found on partly mown plots, or on those plots mown late in the year (Fig. 5). The probability of finding an ant nest was also highest in these management types. However, in all types it was higher than zero.

\section{Changes in the Myrmica community}

The probability of finding a Myrmica nest on a plot was equal for all years, except for 2003, when it was significantly lower (Appendix A2). Furthermore, there is a much higher probability of finding a nest in nature reserves compared to road verges and ditch edges. For the Myrmica community as a whole, the exposition of a plot could not be added to the model, but the distance to a tree appears to be important: The closer the tree, the greater 
Table 2 Results of the statistical analysis of the impact of habitat characteristics on presence/absence patterns of ant species and abundance of ant nests by using generalized estimation equations (GEE's)

\begin{tabular}{|c|c|c|c|c|c|c|c|}
\hline Dependent variable & $\mathrm{P} / \mathrm{A}$ & $n$ & QICC & Predictor & Wald chi-square & df & $P$ \\
\hline \multirow[t]{4}{*}{ All ant species } & \multirow[t]{4}{*}{$\mathrm{P}$} & \multirow[t]{4}{*}{955} & \multirow[t]{4}{*}{1119,097} & Year & 62,640 & 4 & $<0.0001$ \\
\hline & & & & Municipality & 15,195 & 3 & 0.002 \\
\hline & & & & Slope direction & 26,590 & 7 & $<0.0001$ \\
\hline & & & & Distance to tree & 14,079 & 5 & 0.015 \\
\hline \multirow[t]{3}{*}{ All ant species } & \multirow[t]{3}{*}{ A } & \multirow[t]{3}{*}{606} & \multirow[t]{3}{*}{7655,069} & Year & 43,662 & 4 & $<0.0001$ \\
\hline & & & & Municipality & 20,663 & 3 & $<0.0001$ \\
\hline & & & & Slope direction & 43,390 & 7 & $<0.0001$ \\
\hline \multirow[t]{3}{*}{ All Myrmica species } & \multirow[t]{3}{*}{$\mathrm{P}$} & \multirow[t]{3}{*}{955} & \multirow[t]{3}{*}{1020,500} & Year & 27,276 & 4 & $<0.0001$ \\
\hline & & & & Municipality & 68,167 & 3 & $<0.0001$ \\
\hline & & & & Distance to tree & 15,362 & 5 & 0.009 \\
\hline \multirow[t]{2}{*}{ All Myrmica species } & \multirow[t]{2}{*}{ A } & \multirow[t]{2}{*}{606} & \multirow[t]{2}{*}{3257,416} & Municipality & 60,156 & 3 & $<0.0001$ \\
\hline & & & & Abundance $L$. niger & 6,023 & 1 & 0.014 \\
\hline \multirow[t]{3}{*}{ Myrmica scabrinodis } & \multirow[t]{3}{*}{$\mathrm{P}$} & \multirow[t]{3}{*}{955} & \multirow[t]{3}{*}{874,669} & Municipality & 33,583 & 3 & $<0.0001$ \\
\hline & & & & Slope direction & 21,144 & 7 & 0.004 \\
\hline & & & & Distance to tree & 12,975 & 5 & 0.024 \\
\hline \multirow[t]{3}{*}{ Myrmica scabrinodis } & \multirow[t]{3}{*}{ A } & \multirow[t]{3}{*}{606} & \multirow[t]{3}{*}{2001,333} & Municipality & 16,012 & 3 & 0.001 \\
\hline & & & & Slope direction & 26,501 & 7 & $<0.0001$ \\
\hline & & & & Abundance $L$. niger & 16,687 & 1 & $<0.0001$ \\
\hline \multirow[t]{2}{*}{ Myrmica rubra } & \multirow[t]{2}{*}{$\mathrm{P}$} & 955 & 569,867 & Year & 17,552 & 4 & 0.002 \\
\hline & & & & Municipality & 11,753 & 3 & 0.008 \\
\hline Myrmica rubra & A & 606 & 1433,194 & Year & 16,499 & 4 & 0.002 \\
\hline & & & & Municipality & 12,229 & 3 & 0.007 \\
\hline & & & & Slope direction & 22,654 & 7 & 0.002 \\
\hline & & & & Abundance $L$. niger & 13,465 & 1 & $<0.0001$ \\
\hline Lasius niger & $\mathrm{P}$ & 955 & 1057,108 & Year & 47,933 & 4 & $<0.0001$ \\
\hline & & & & Municipality & 52,685 & 3 & $<0.0001$ \\
\hline & & & & Slope direction & 24,329 & 7 & 0.001 \\
\hline Lasius niger & A & 606 & 2523,641 & Year & 55,538 & 4 & $<0.0001$ \\
\hline & & & & Municipality & 86,675 & 3 & $<0.0001$ \\
\hline & & & & Slope direction & 16,795 & 7 & 0.019 \\
\hline Lasius flavus & $\mathrm{P}$ & 955 & 727,982 & Year & 21,039 & 4 & $<0.0001$ \\
\hline & & & & Municipality & 23,339 & 3 & $<0.0001$ \\
\hline & & & & Slope direction & 53,003 & 7 & $<0.0001$ \\
\hline & & & & Abundance L. niger & 26,132 & 1 & $<0.0001$ \\
\hline Lasius flavus & A & 606 & 3082,072 & Year & 14,225 & 4 & 0.007 \\
\hline & & & & Slope direction & 45,867 & 7 & $<0.0001$ \\
\hline & & & & Distance to tree & 13,612 & 5 & 0.018 \\
\hline
\end{tabular}

For the analysis of the abundance, all plots without ants were excluded. The data were collected during 5 years on 179 plots in The Netherlands. Explanation of field names: $P / A$ presence-absence $(\mathrm{P})$ or abundance (A) analysis, $n$ sample size, QICC corrected quasi likelihood under independence model criterion, $d f$ degrees of freedom, $P$ significance

the chance of finding Myrmica ants. Similarly, a high probability of occurrence was found at distances greater than 20 metres. The density of nests on a plot could only be explained by the variable municipality and by the abundance of $L$. niger. Densities are highest in nature reserves, and also when there are low densities of the competitor ant species (Table 2, Appendix B2). While no significant effect of management type on the occupation pattern of the Myrmica ants could be found (GLM, Wald $\left.\chi^{2}=8.467, \mathrm{df}=5, P=0.132\right)$, there was a clear effect on their abundance (GLM, Wald $\chi^{2}=17.215$, $\mathrm{df}=6$, $P=0.009$ ). Even though the Myrmica ants do not make 
up the major part of the ant community, most of them were found in the same management types, that is, on partly mown plots, or those plots that were mown late in the year.

\section{M. scabrinodis and M. rubra}

M. scabrinodis is found mainly in the nature reserves, even though it is the second-most abundant species on road verges (Appendix A3). On the meadows in the nature reserves it also reaches its highest densities. In addition, level plots are preferred to those on a slope. The distance to trees has a significant impact on the occupation probability but it does not show a clear pattern. A great abundance of L. niger clearly affects M. scabrinodis negatively (Table 2, Appendix B3).

In 2003, the probability of finding M. rubra and its density of colonies were significantly lower relative to all other years (Table 2, Appendixes A4, B4). We found the highest occupation probabilities and abundances in the nature reserves and along roads in the municipality of Vught. In addition, nest densities decreased when there were many colonies of $L$. niger nearby. Management of the road verges had no effect on the probability of finding a nest of M. scabrinodis (GLM, occupation Wald $\chi^{2}=1.860, \quad \mathrm{df}=66, \quad P=0.868 ; \quad$ abundance Wald $\left.\chi^{2}=5.186, \mathrm{df}=6, P=0.52\right)$. In contrast, plot occupation by $M$. rubra was linked to management (GLM, Wald $\left.\chi^{2}=7.730, \mathrm{df}=2, P=0.021\right)$. The highest probability was found on plots mown late in the year. Mowing early or partly had a significantly lower probability, while in plots with all other management types this species was absent. This result is even more pronounced when analysing the abundance (GLM, Wald $\chi^{2}=15.606$, df $=6, P=0.016$, Fig. 5).

\section{L. flavus and L. niger}

L. flavus and L. niger show contrasting results with regard to changes in occupation and abundance over the years, even though the factors of importance are the same (Table 2, Appendixes A5, A6, B5, B6). L. flavus is a species mostly found in nature reserves, while $L$. niger has both highest probability of occupation and abundance on road verges. $L$. niger is also the only ant species with a high abundance in the year 2003. On the road verges, management had no effect on the presence-absence patterns of either species (GLM L. flavus, Wald $\chi^{2}=6.042$, df $=5$, $P=0.302$, GLM L. niger Wald $\chi^{2}=10.313$, $\mathrm{df}=6$, $P=0.112$ ), but it was important in explaining the abundance. Most nests of L. flavus were found on the partly mown plots, whereas the species seems to avoid the unmown plots and the plots covered with ditch sediment (GLM, Wald $\chi^{2}=64.692, \mathrm{df}=6, P<0.0001$, Fig. 5). L. niger found its highest abundance in the partly mown plots or where flail cutting was applied (GLM, Wald $\chi^{2}=87.435$, df $=6, P<0.0001$, Fig. 5).

\section{Discussion}

Our study shows that not only nature reserves, but also road verges and ditch edges, provide a habitat for the host ant species of the butterflies $P$. nausithous and $P$. teleius. However, their occurrences and densities are lower in the linear landscape elements. Although a comparison is difficult due to differences in geographical location and site characteristics, the meadows in our nature reserves and the road verges seem to be of moderate ant species richness. In Germany, 3-12 ant species of open habitats were found in traditionally managed grassland (Dauber and Wolters 2000; Seifert 1986; Dahms et al. 2005). In Poland, Woyciechowski and Miszta (1976) and Petal (1974, 1980) found 4-14 ant species on the moist meadows where the source populations of the reintroduced butterflies occur. On such meadows, $M$. scabrinodis usually dominates the ant community (Grill et al. 2008; Witek et al. 2008), which agrees with our findings. On road verges, however, L. niger is by far the commonest species. This species can withstand the disturbance associated with roads, such as frequent management, whereas Myrmica ants prefer less dynamic sites with mowing only once or twice a year, or even less, as in nature reserves or agricultural land under traditional management (Peeters et al. 2004). In such stable conditions, they can outcompete L. niger (Dauber and Wolters 2004). On road verges, $L$. niger is able to reduce the abundance of Myrmica ants in general, and M. scabinodis in particular, confirming its role in structuring the ant community.

In the summer of 2001, the road verges with the largest subpopulation of $P$. nausithous and the highest presence and abundance of $M$. rubra, was covered unintentionally by a layer of sand because of road works. Many monitoring plots were affected. The occurrence of ants was reduced from $78 \%$ in 2001 to $32 \%$ in 2002 and nest densities also decreased with more than 50\%. While the Myrmica species suffered most, L. niger had already increased its nest density in 2002, later followed by increases in occupation (Wynhoff, unpublished data). The low values found for presence-absence and abundance of M. rubra in 2003 are probably also due to this accidental habitat destruction in 2001. 

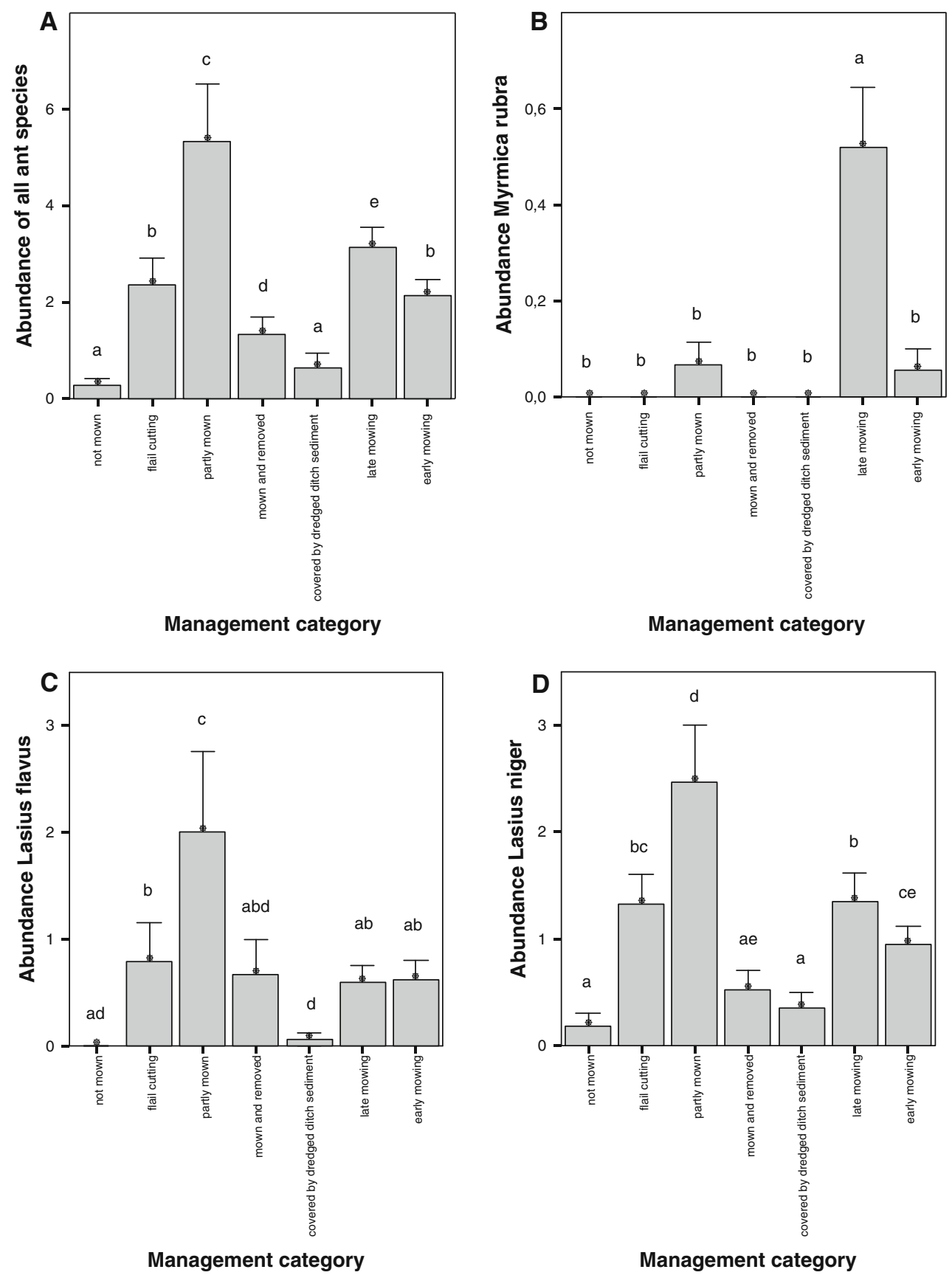

Fig. 5 Mean abundance of ant species on monitoring plots on the road verges in the municipalities of Den Bosch, Heusden and Vught in relation to plot management (Province of Noord-Brabant, The Netherlands). a all ant species, b Myrmica rubra, c Lasius flavus, d Lasius niger

Although the host plant S. officinalis is widespread on the road verges in the Maculinea Action Plan Area, the ants are much rarer. Therefore the impression that the majority of the road verges with the host plant are potential habitat for the expanding Phengaris butterflies is not supported by our data. Only between 20 and $40 \%$ of the plots were occupied by Myrmica ants. No ants could be found in the vicinity of $25-50 \%$ of the studied host plants. Caterpillars on these plants thus have hardly any chance of being found and adopted by a Myrmica ant. Earlier studies showed that the neighbouring agricultural land is virtually ant-free (Wynhoff et al. 2008). Due to modern agricultural techniques, such as frequent ploughing, manure injection and heavy grazing by cattle, invading ant colonies have only 
little chance of survival. When ants are found in arable land, both species-richness and nest densities are low (Dauber and Wolters 2004; Dahms et al. 2005; Dauber et al. 2006).

Site characteristics independent from management were found to have an impact on the local ant community. These are mainly related to the local microclimate. Since it was not possible to measure soil temperature or insolation at so many locations, we used the slope of the plot and its distance to the nearest tree as a proxy for microclimate. When the exposition of the slope was found to be significant, the highest probability of occupation or the highest predicted abundance was found on slopes with southern or western exposition, which receive sunlight for the longest time of the day and are therefore warmest. This result is to be expected for thermophilous insects like ants. The distance to trees affected presence-absence patterns, with a higher probability of occupation at closer distance but only up to $10 \mathrm{~m}$ as a tree close to an ant colony gives shade in the hottest hours of the day. Further away, the benefit seems to be rather coincidental.

The management types investigated have various effects on the ant species. Not only is this revealed for a certain management, but also illustrated by the differences between the municipalities, each of which is responsible for its own road verge management. In the nature reserve, management usually remains the same for years and is beneficial for nature. Hay meadows are cut once a year and the hay is removed after about a week of drying. Since 1990, cutting between mid-June and mid-September has been avoided in all meadows occupied by Phengaris butterflies. With one mowing a year, M. scabrinodis can dominate the community and can reach high densities with locally more than one colony per square metre, thus providing a high quality habitat for $P$. teleius. This supports the results found by Grill et al. (2008) in Phengaris habitats in Bavaria. On the road verges, factors such as traffic safety, water flow through the ditches and efficient use of mowing machines, like flail cutters, also affect management regimes, resulting in a much more dynamic environment for the ants, and consequently, in different ant communities. We found that highest abundance of ants is achieved by mowing only parts of the vegetation. In the unmown parts, ants are not disturbed and their nests are not destroyed, making it easy to recolonize the short cut part. The fast colonizer L. niger mainly profits from this management, but also L. flavus is able to sustain with a high nest density, probably because the high nest mounds of L. flavus are situated in the abandoned part of the vegetation and are therefore not disturbed. However, our data do not allow to prove this because we searched for ants along the whole gradient from the asphalt layer over the flat grassy verge down to the bottom of the neighbouring ditch. In addition, variation in vegetation structure and the amount of edge habitat are increased by mowing only the strip along the road, which is also beneficial for the ant community (Dauber and Wolters 2004; Golden and Crist 2000). The host ant of P. teleius, M. scabrinodis, seems to profit from mowing early in June, even though this effect was not significant in our analysis. On the meadows in the nature reserves, vegetation is usually mown in autumn, and nest densities of this ant species are even higher. These meadows are on poor soils without fertilization, that allows for late mowing. The vegetation cover stays open and does not prevent the sun from warming the soil. However, since late mowing does not prevent bush encroachment and colonization of these wet meadows by willows, every fifth year meadows are cut early, without having a negative effect on M. scabrinodis so far. If cut sufficiently early, the Sanguisorba plants are able to produce new buds in time for the females of $P$. teleius to deposit their eggs. On the road verges the soil is nutrient richer and has a denser vegetation. Here, M. scabrinodis is best supported by early mowing. Statistical analysis did not reach significance, but the probability of occupation on road verges was highest in the municipality of Den Bosch, where most plots are mown early in the year.

In contrast, $M$. rubra, the host ant of $P$. nausithous, profits from mowing late in autumn. This ant species is less thermophilous than M. scabrinodis. High vegetation provides sheltered nest locations where the ants are less subject to the heat during summer. In the nature reserve, the species thrives only on edges along high vegetation, such as beds of tall reed and willow forest edges. Probably due to climatic requirements, at the study site, $M$. rubra co-occurs only rarely with M. scabrinodis, as it usually does within the range of the butterflies in Europe (Elmes et al. 1998). Mowing only parts of the vegetation could be expected to be beneficial for M. rubra, because the colonies can survive in the unmown parts. However, there are more beneficial effects for the Lasius species, which are able to reduce the nest density of Myrmica species. A disadvantage of regular late mowing is that nutrients are not removed from the plots. This in turn allows shrubs, tall herbs and grasses to overgrow the Sanguisorba plants and prevent them from flowering. Therefore, once every 3-6 years, depending on the nutrient richness of the soil and the productivity of the vegetation, road verges should be mown early.

L. niger profits most from flail cutting, a method, which is not beneficial to the other ant species but most costefficient for the municipalities. It leaves a layer of dead organic material on the vegetation preventing the sun to warm up the soil and the ant nests. Furthermore, L. niger has a significant negative effect on the abundance of all Myrmica-species. As a strong competitor, it not only shapes the ant community on the road verges and ditch 
edges, but also the habitat quality of these linear elements for Phengaris butterflies.

\section{Recommendations for conservation}

Our results suggest that management benefitting Phengaris butterflies should aim to increase nest densities of Myrmica species (see also Anton et al. 2008; Dierks and Fischer 2009) whereas L. niger should decrease or at least be kept at a low level of occupation with low nest densities. Furthermore, it is important not to mow the habitat of the butterflies between mid-June and mid-September, because this would destroy temporarily locations with both host ants and flowering host plants, and females would not being able to deposit their eggs on these sites. Although our results show that certain types of management should not be applied, they are less clear about what to do best. Unfavourable actions include not mowing or using road verges to deposit ditch detritus. Here, microclimate will change into shady and cool conditions, where ant nests cannot persist anymore. In the habitat and the surroundings of the Dutch Phengaris populations, the best option to support Myrmica species is mowing once per year. However, this still leaves three possibilities open: cutting only parts of the vegetation, mowing before mid-June or mowing after mid-September. Our results suggest that M. scabrinodis is best supported by early mowing of the road verge vegetation, or by late mowing in the nature reserves. The best management for the host ant of $P$. nausithous, M. rubra, appears to be mowing late in September or October, as the municipality of Vught does on most of its road verges. With different mowing regimes required for the two Myrmica species, some flexibility is needed to promote both butterfly species. The best mosaic pattern of early cut road verge vegetation with parts left until autumn would be realized by mowing one side of the road early, and the other one late. The butterflies can cross rural roads, and when they leave an ant nest on the mown side after pupation, they can find mates and host plants at the other side. Since $P$. nausithous is much more dependent on road verges as a permanent habitat (Van Langevelde and Wynhoff 2009), a scheme of late mowing with early mowing periodically, should be realised here, at least for the sites within the dispersal range of the species. In the Moerputten, P. teleius is much more dependent on meadows for reproduction, and it uses road verges mainly for dispersal (Van Langevelde and Wynhoff 2009).

Restoring wet meadows and marshes for the butterflies requires not only suitable habitat conditions, but also good colonization probabilities. Plant species which are not able to colonize by themselves can be brought to the sites by mowing the meadows in the nature reserves and transporting the seed by spreading the hay in the restored sites (Klimkowska et al. 2007; Rasran et al. 2007). The ants have to colonize these sites mainly from the linear elements by walking to them after having split off from the colony. Therefore, to facilitate the restoration, careful management of vegetation in these linear elements is needed. Up till now, translocation of ant nests has proven to be difficult (Pontin 1969; Elmes 1971). Until new methods have been developed, it will be crucial to build up densities of Myrmica nests in restored sites that are needed to make sustainable populations of Phengaris butterflies. Even when road verge populations will be at close distance, L. niger will be the first species to colonize the new sites. Our results suggest that only when the vegetation of the meadow is dense, and a constant management of one or two cuts a year has been established, Myrmica species will be able to outcompete L. niger.

Acknowledgments We want to thank Sicco Ens, Sergej Jansen, Saskia Janssen, Gerard Oostermeijer, Nicoliene Peet, Maarten van Steenis and Agnieszka Bucholc for field work assistance and Nicoliene Peet for her help with the ant identification. Claire and Rob Hengeveld kindly corrected the English. National State Forestry and Natuurmonumenten gave us permission to enter their nature reserves. IW was funded by the Province of Noord-Brabant.

Open Access This article is distributed under the terms of the Creative Commons Attribution Noncommercial License which permits any noncommercial use, distribution, and reproduction in any medium, provided the original author(s) and source are credited.

\section{Appendix A}

Probability of occupation of ant species as significant predictors on dependent variables, analyzed by Generalized Estimation Equations (GEE's, see text for details). The data were collected on 179 monitoring plots during 5 years of investigation in the Moerputten nature reserve and surrounding road verges and ditch edges in The Netherlands. The variables are the year of investigation, the municipality responsible for the management, the slope direction of the plot, the distance to the nearest tree or shrub in distance classes and the abundance of Lasius niger. Only significant results are presented.

A1: all ant species combined, A2: all Myrmica species combined, A3: Myrmica scabrinodis, A4: Myrmica rubra, A5: Lasius niger, A6: Lasius flavus 

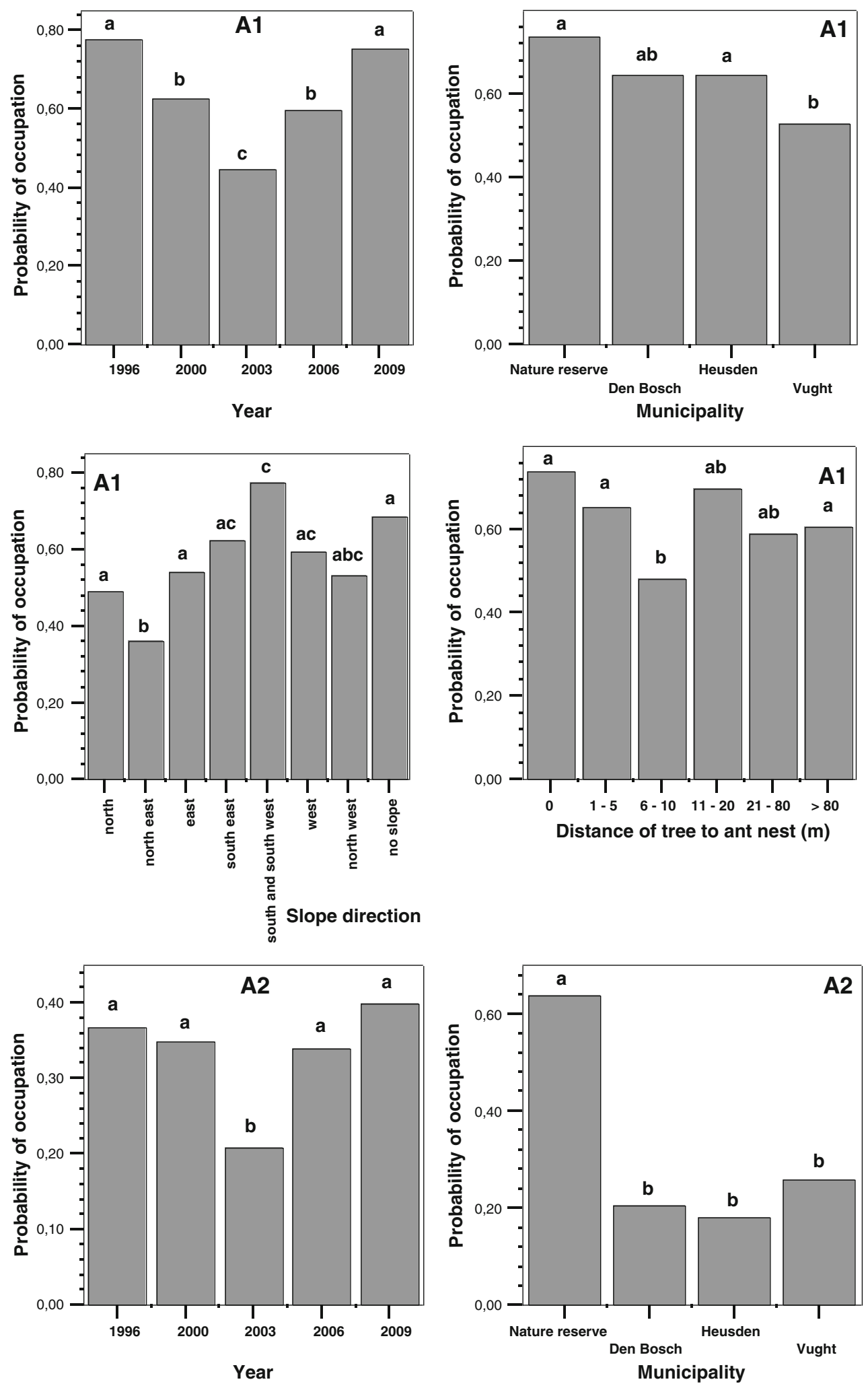

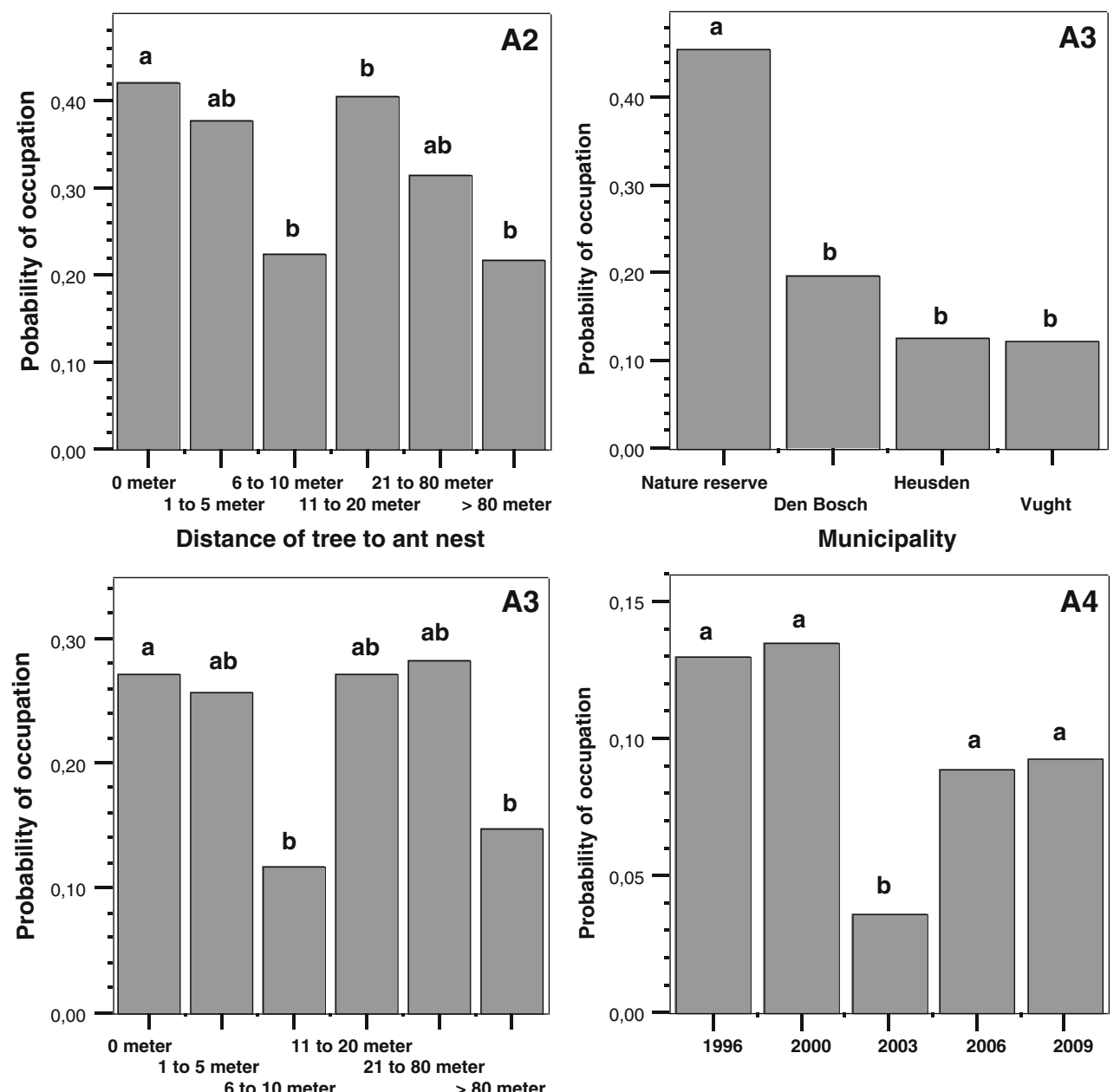

Distance of tree to ant nest
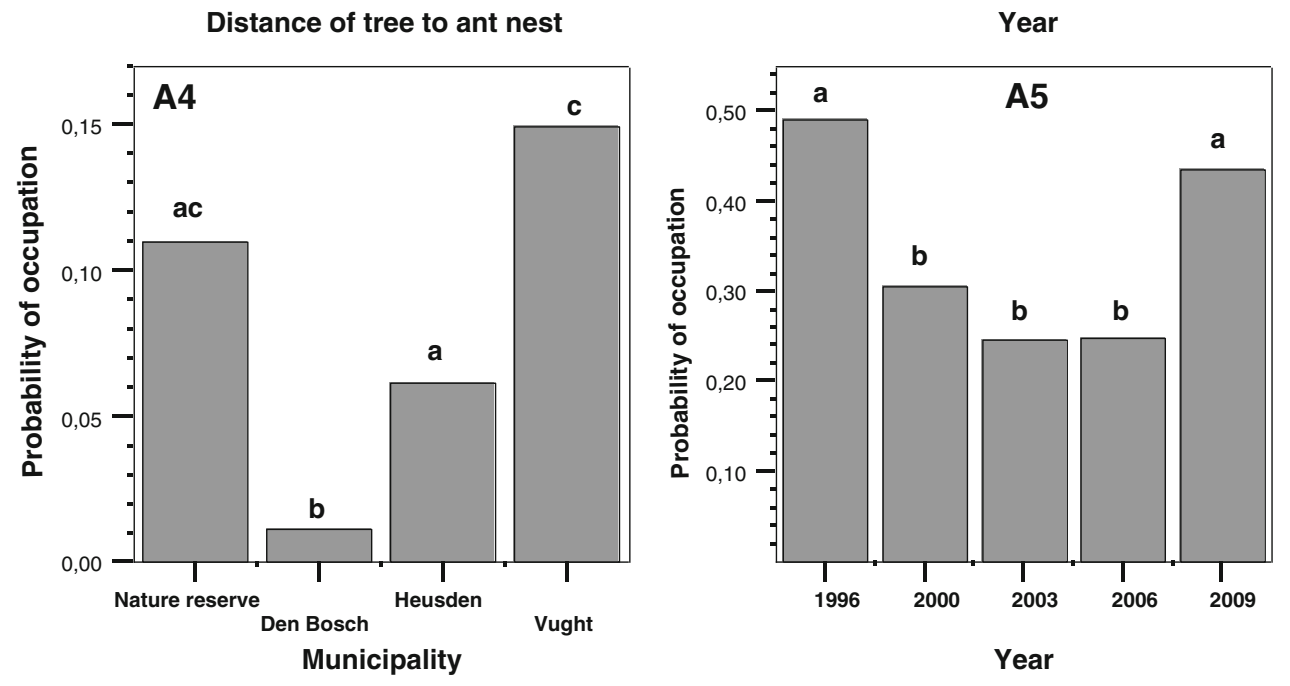

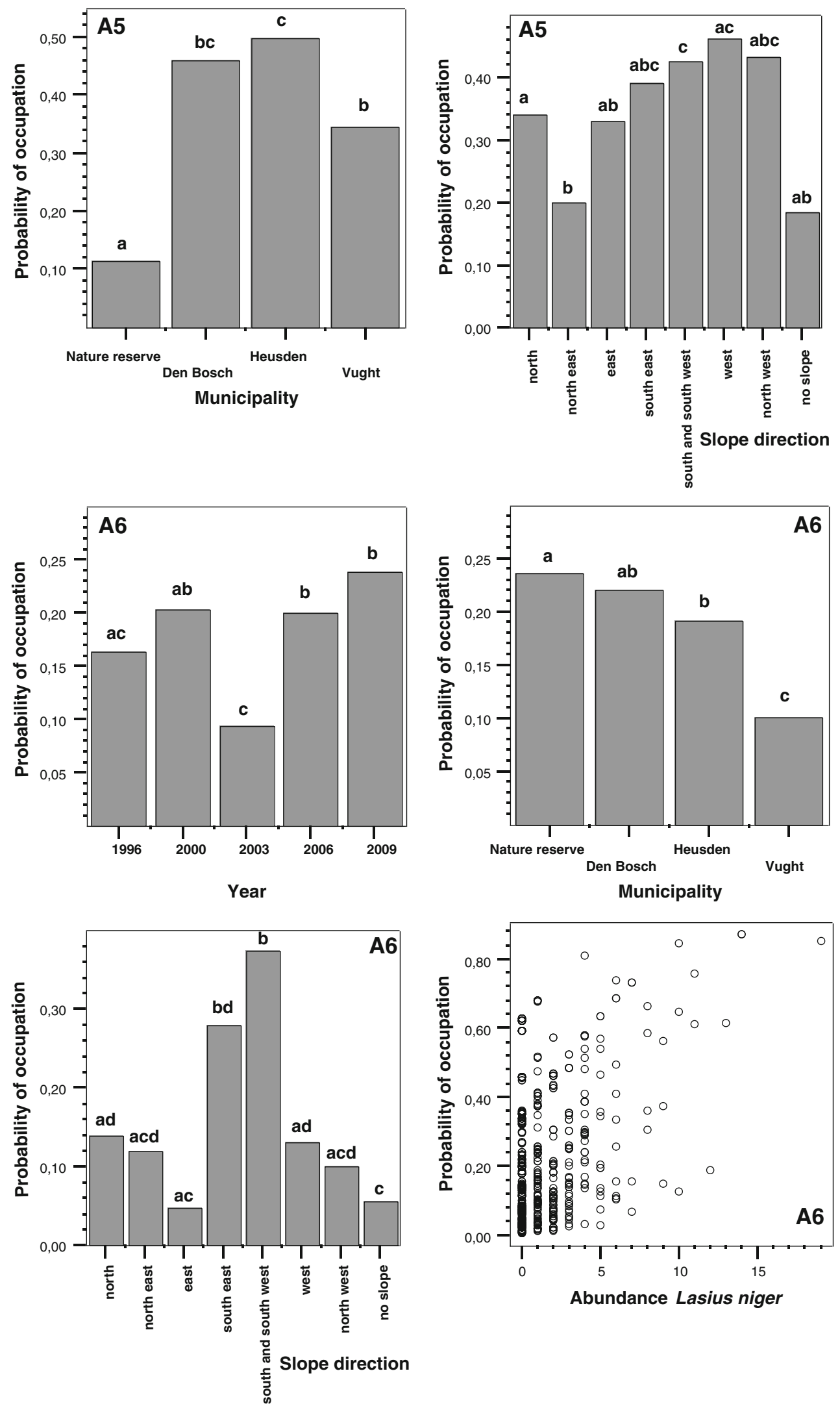

Abundance Lasius niger 


\section{Appendix B}

Predicted abundance of ant nests as significant predictors in relation to dependent variables, analyzed by Generalized
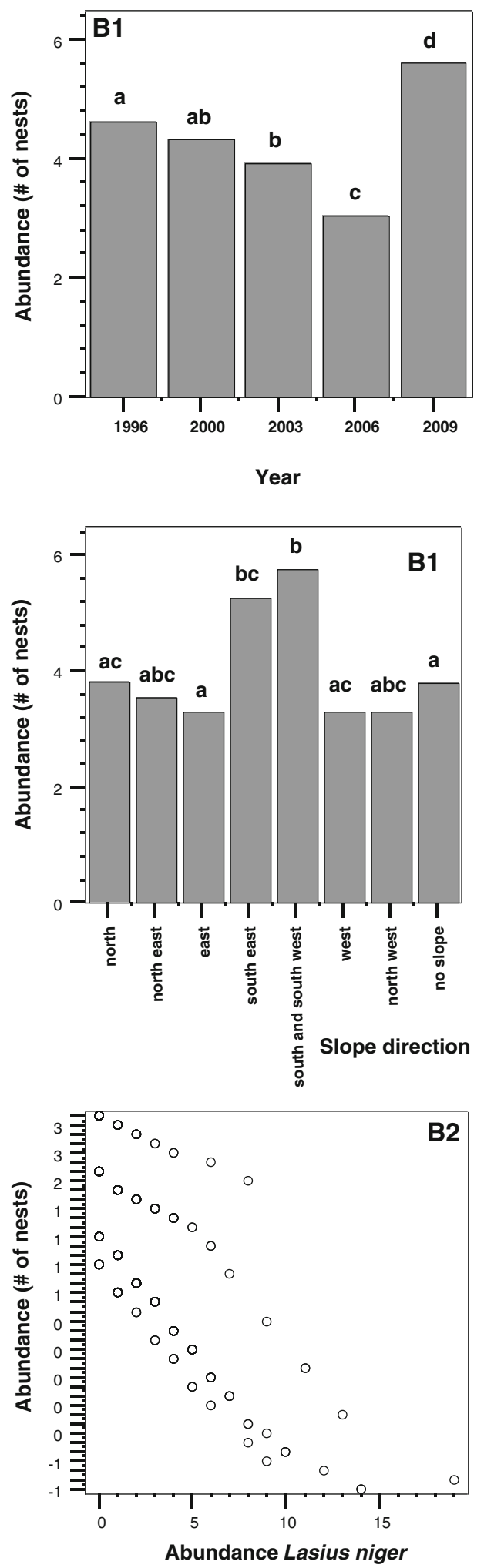

Estimation Equations (GEE's, see text for details). The data were collected on 179 monitoring plots during 5 years of investigation in the Moerputten nature reserve and surrounding road verges and ditch edges in The Netherlands.
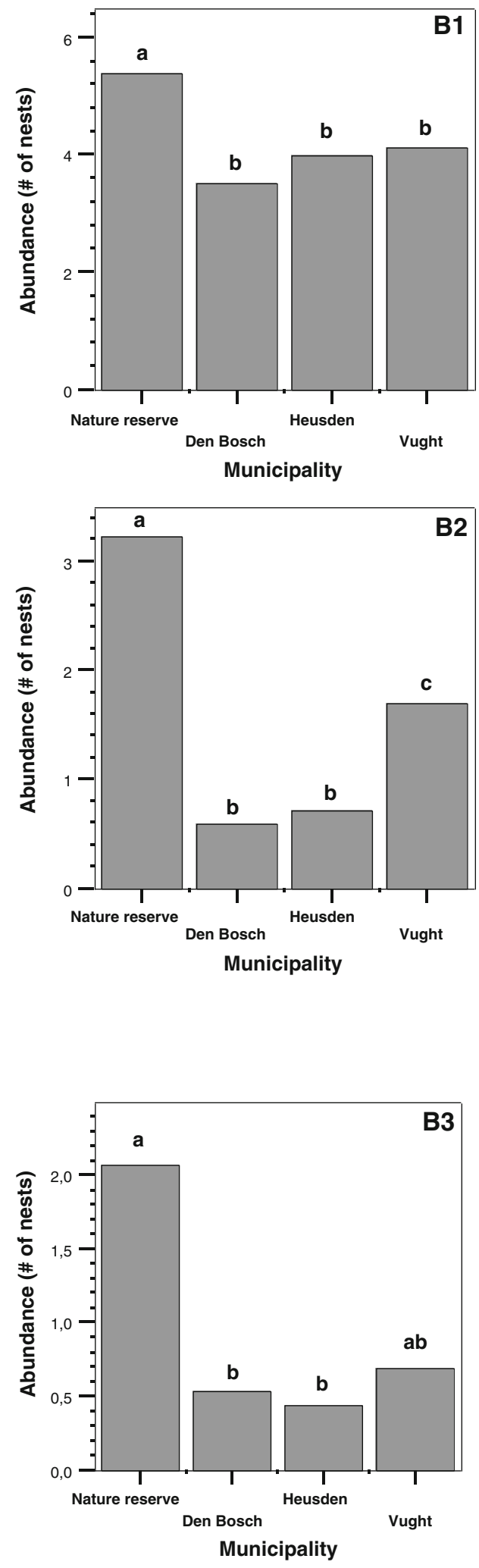

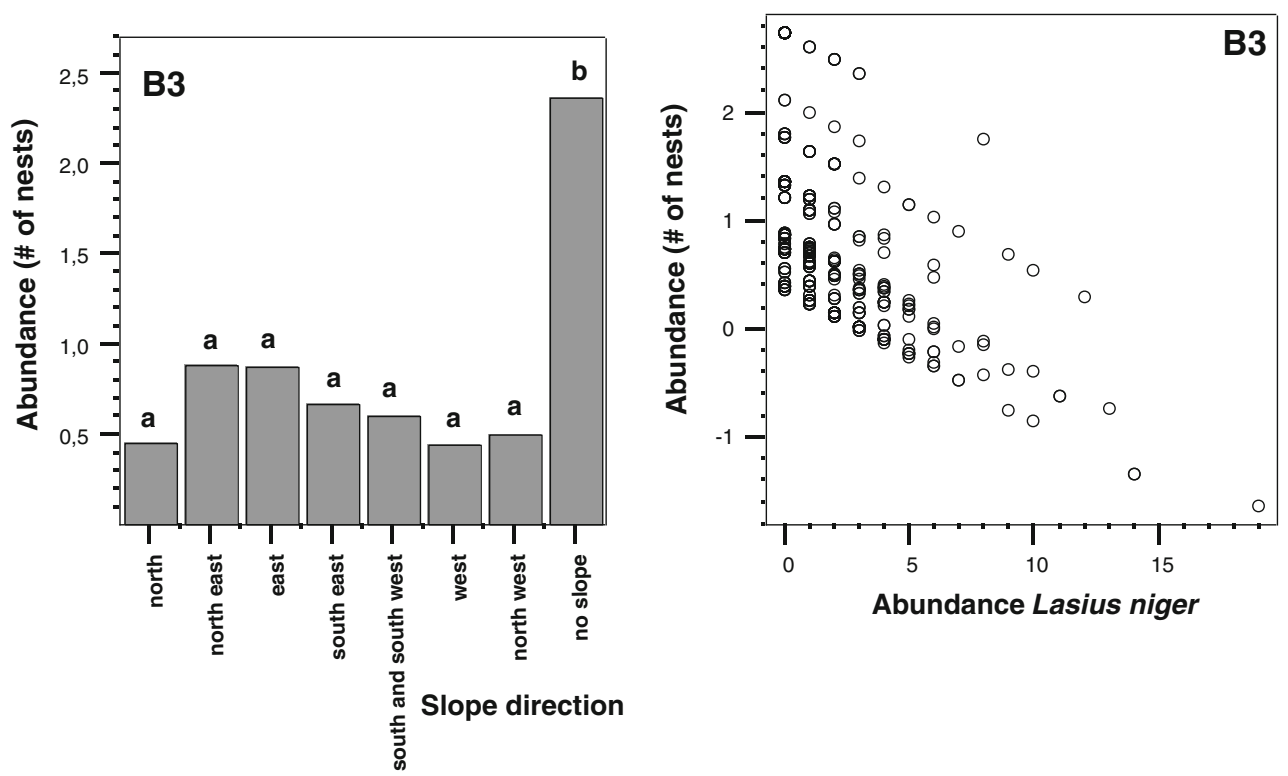

Abundance Lasius niger
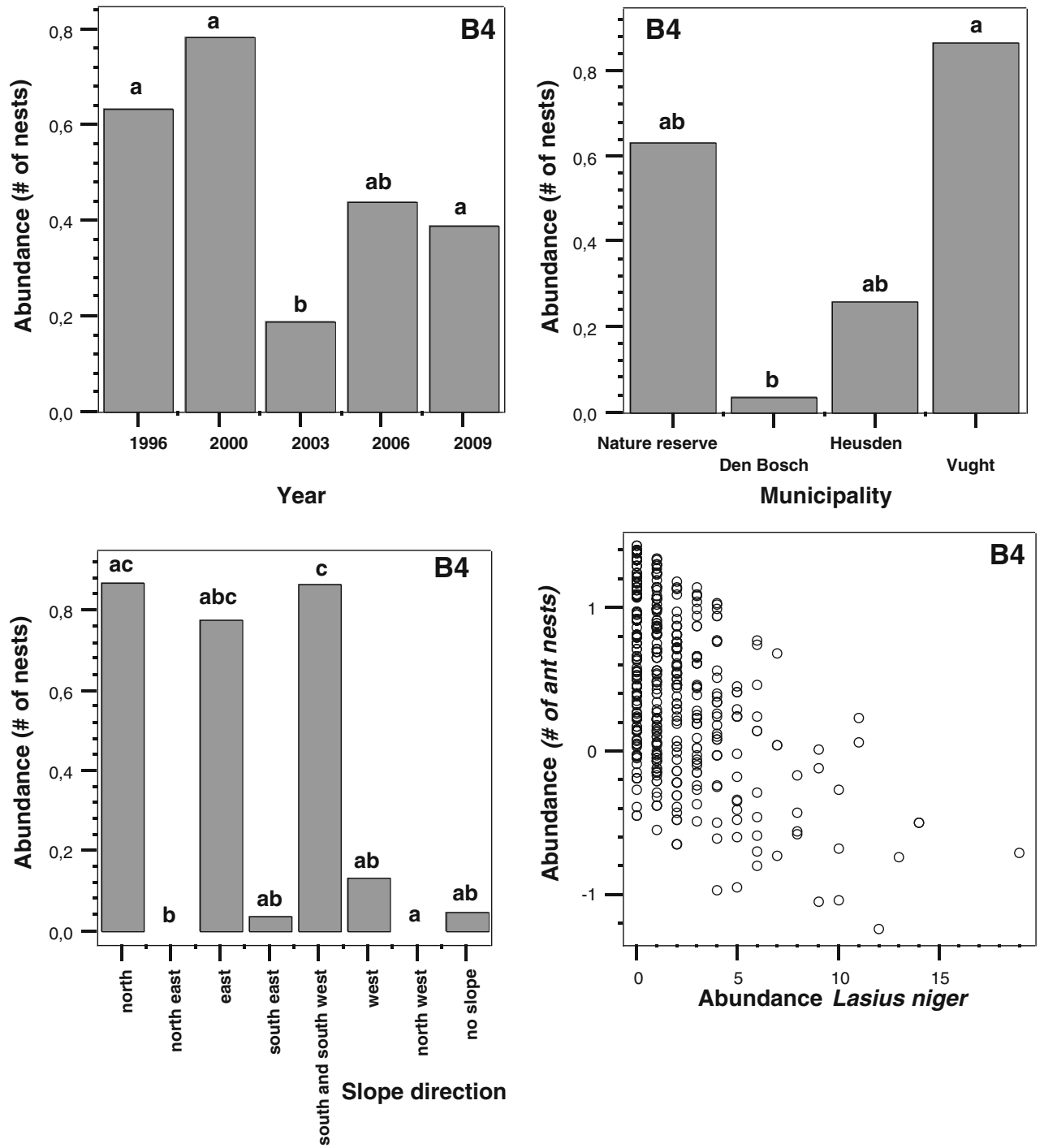

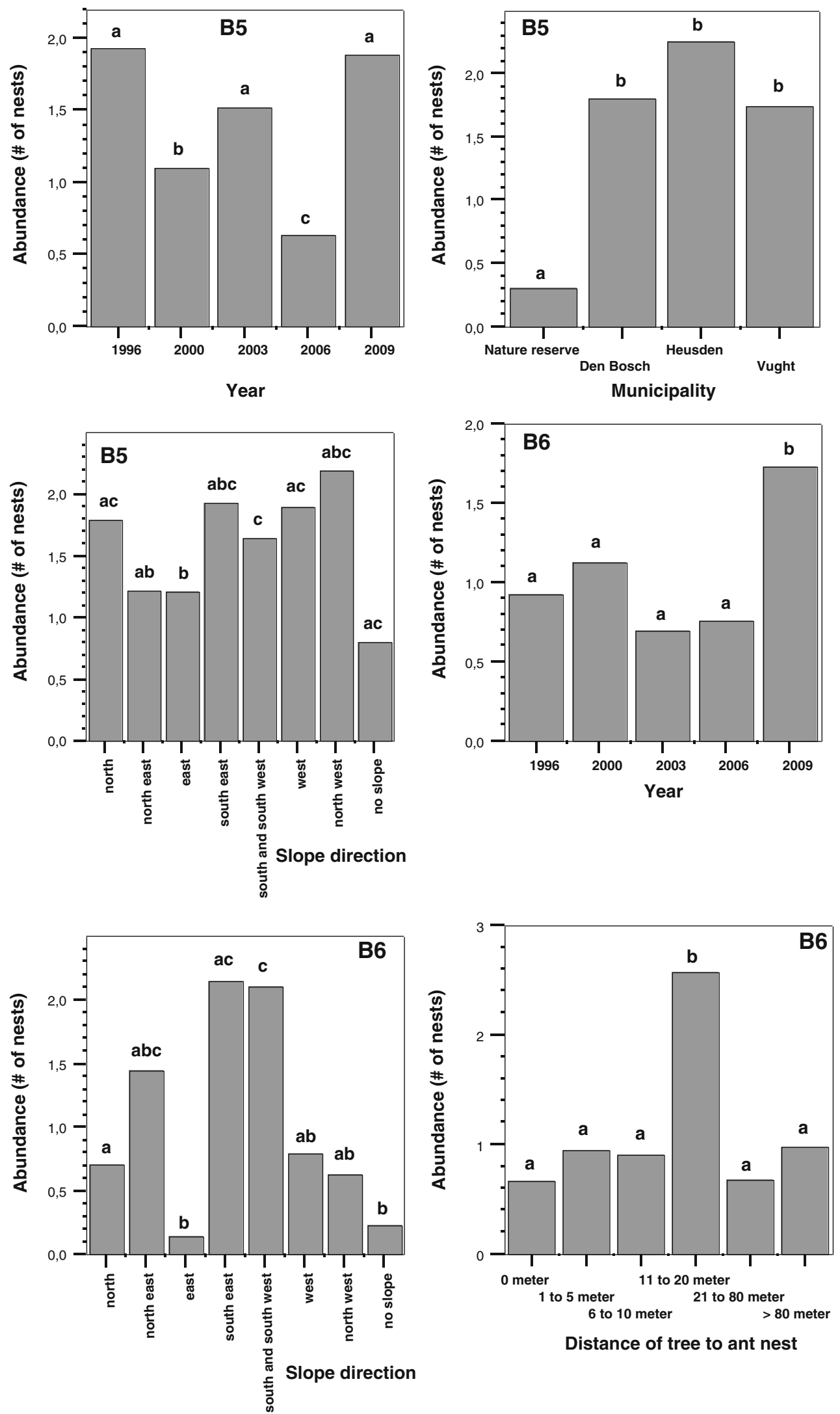
The variables are the year of investigation, the municipality responsible for the management, the slope direction of the plot, the distance to the nearest tree or shrub in distance classes and the abundance of Lasius niger. Only significant results are presented.

B1: all ant species combined, B2: all Myrmica species combined, B3: Myrmica scabrinodis, B4: Myrmica rubra, B5: Lasius niger, B6: Lasius flavus

\section{References}

Anton C, Musche M, Hula V, Settele J (2008) Myrmica host-ants limit the density of the ant-predatory large blue Maculinea nausithous. J Insect Conserv 12:511-517

Armbrecht I, Perfecto I, Vandermeer J (2004) Enigmatic biodiversity correlations: ant diversity responds to diverse resources. Science 304:284-286

Batáry P, Kőrösi Á, Őrvőssy N, Kővér S, Peregovits L (2009) Species-specific distribution of two sympatric Maculinea butterflies across different meadow edges. J Insect Conservation 13(2):223-230

Curry JP (1994) Grassland invertebrates. Chapman \& Hall, Cambridge Dahms H, Wellstein C, Wolters V, Dauber J (2005) Effects of management practices on ant species richness and community composition in grasslands (Hymenoptera: Formicidae). Myrmecologische Nachrichten 7:9-16

Dauber J, Bengtsson J, Lenoir L (2006) Evaluating habitat loss and land-use continuity on ant species richness in seminatural grassland remnants. Conserv Biol 20(4):1150-1160

Dauber J, Wolters V (2000) Diversität der Ameisenfauna im Landnutzungsmosaik einer peripheren Region. Mitteilungen der Deutschen Gesellschaft für allgemeine und angewandte Entomologie 12:281-284

Dauber J, Wolters V (2004) Edge effects on ant communty structure and species richness in an agricultural landscape. Biodivers Conserv 13:901-915

Dierks A, Fischer K (2009) Habitat requirements and niche selection of Maculinea nausithous and M. teleius (Lepidoptera: Lycaenidae) within a large sympatric metapopulation. Biodivers Conserv 18:3663-3676

Elmes GW (1971) An experimental study on the distribution of heathland ants. J Anim Ecol 40(2):495-499

Elmes GW, Thomas JA, Wardlaw JC, Hochberg ME, Clarke RT, Simcox DJ (1998) The ecology of Myrmica ants in relation to the conservation of Maculinea butterflies. J Insect Conserv 2:67-79

Elmes GW, Wardlaw JC (1982) A population study of the ants Myrmica sabuleti and Myrmica scabrinodis, living at two sites in the south of England. I. A comparison of colony populations. J Anim Ecol 51:651-664

Golden DM, Crist TO (2000) Experimental effects of habitat fragmentation on rove beetles and ants: patch area or edge? Oikos 90:525-538

Grill A, Cleary DFG, Stettmer C, Bräu M, Settele J (2008) A mowing experiment to evaluate the influence of management on the activity of host ants of Maculinea butterflies. J Insect Conserv 12(6):617-627

Haddad N (2000) Corridor length and patch colonization by a butterfly, Junonia coenia. Conserv Biol 14:738-745
Heller G, Rohe W (2000) Vergleichende Untersuchung zur Ameisenfauna von Grünlandstandorten in Rheinland-Pfalz. Mainzer Naturwissenschaftliches Archiv 38:123-173

Klimkowska A, Van Diggelen R, Bakker JP, Grootjans AP (2007) Wet meadow restoration in Western Europe: a quantitative assessment of the effectiveness of several techniques. Biol Conserv 140:318-328

Kruess A, Tscharntke T (2002) Grazing intensity and the diversity of grasshoppers, butterflies, and trap-nesting bees and wasps. Conserv Biol 16:1570-1580

Peeters TMJ, van Achterberg C, Heitmans WRB, Klein WF, Lefeber V, van Loon AJ, Mabelis AA, Nieuwenhuijsen H, Reemer M, de Rond J, Smits J, Velthuis HHW (2004) De wespen en mieren van Nederland (Hymenoptera: Aculeata)-Nederlandse Fauna 6. Nationaal Natuurhistorisch Museum Naturalis, Leiden, KNNV Uitgeverij, Utrecht \& European Invertebrate Survey Nederland, Leiden

Petal J (1974) Analysis of a sheep pasture ecosystem in the Pieniny Mountains (the Carpathians) XV. The effect of pasture management on ant population. Ekologia Polska 22:679-692

Petal J (1980) Ant populations, their regulation and effect on soil in meadows. Ekologia Polska 28:297-326

Pontin AJ (1969) Experimental Transplantation of nest mounds of the ant Lasius flavus (F.) in a habitat containing also L. niger (L.) and Myrmica scabrinodis Nyl. J Anim Ecol 38(3):747-754

Provincie Noord-Brabant (1997) Beheersconvenant in het kader van het Beschermingsplan Pimpernelblauwtjes bij Den Bosch. Provincie Noord-Brabant, Den Bosch

Rasran L, Vogt K, Jensen K (2007) Effects of topsoil removal, seed transfer with plant material and moderate grazing on restoration of riparian fen grasslands. Appl Veg Sci 10:451-460

Seifert B (1986) Vergleichende Untersuchungen zur Habitatwahl von Ameisen (Hymenoptera: Formicidae) im mittleren und südlichen Teil der DDR. Abh Ber NaturkundemusGörlitz 59: $1-124$

Seifert B (1994) Die freilebenden Ameisen Deutschlands (Hymenoptera: Formicidae) und Angaben $\mathrm{zu}$ deren Taxonomie und Verbreitung. Abh Ber Naturkundemus Görlitz 67:1-44

Seifert B (1996) Ameisen beobachten, bestimmen. Naturbuch Verlag, Augsburg

Thomas JA (1984) The behaviour and habitat requirements of Maculinea nausithous (the Dusky Large Blue Butterfly) and $M$. teleius (the Scarce Large Blue) in France. Biol Conserv 28:325-347

Thomas JA, Settele J (2004) Butterfly mimics of ants. Nature 432:283-284

Van Boven JKA, Mabelis AA (1986) De mierenfauna van de Benelux (Hymenoptera: Formicidae). Wetenschappelijke Mededelingen KNNV 173:1-64

Van Dyck H, Talloen W, Oostermeijer JGB, Feenstra V, Van der Hidde A, Wynhoff I (2000) Does the presence of ant nests matter for oviposition to a specialized myrmecophilous Maculinea butterfly? Proc R Soc Lond B Biol Sci 267:861-866

Van Langevelde F, Wynhoff I (2009) What limits the spread of two congeneric butterfly species after their reintroduction: quality or spatial arrangement of habitat? Anim Conserv 12:540-548

Van Loon AJ, Mabelis AA (1996) Flora en Fauna 2030. Fase III: Cryptobiota. Mieren (Formicidae). Mededelingen EIS-Nederland 83:1-34

Witek M, Sliwinska E, Skórka P, Nowicki P, Wantuch M, Vrabec V, Settele J, Woyciechowski M (2008) Host ant specificity of large blue butterflies Phengaris (Maculinea) (Lepidoptera: Lycaenidae) inhabiting humid grasslands in East-central Europe. Eur $\mathbf{J}$ Entomol 105:871-877 
Woyciechowski M, Miszta A (1976) Spatial and seasonal structure of ant communities in a mountain meadow. Ekologia Polska 24:577-592

Wynhoff I (1998) Lessons from the reintroduction of Maculinea teleius and M. nausithous in the Netherlands. J Insect Conserv 2:47-57
Wynhoff I, Grutters M, Van Langevelde F (2008) Looking for the ants: selection of oviposition sites by two myrmecophilous butterfly species. Anim Biol 58:371-388

Zeger SL, Liang K-Y, Albert PS (1988) Models for longitudinal data: a generalized estimating equation approach. Biometrics 44:1049-1060 